\title{
Application of Project Management Information Systems in Efficiency Improvement of Quality Management System
}

\author{
Solvita Berzisa \\ Information Technology Institute, Riga Technical University, Kalku 1, Riga, Latvia
}

\begin{abstract}
Project management information systems (PMIS) and quality management system (QMS) are two components in the project oriented organization that helps to achieve required quality of the project product. QMS define quality framework and PMIS helps to ensure quality framework requirement related to the projects. The objective of paper is to evaluate and demonstrate PMIS options for efficiency QMS development and maintenance. QMS requirements are identified according to ISO 9001:2008 standard and PMIS options of efficiency improvement are evaluated according to ISO 9004:2009 self-assessment tool.
\end{abstract}

Keywords: quality management system, project management information system, PMIS configuration, ISO 9001.

\section{INTRODUCTION}

For increase of competitiveness and productivity and improve performance an organization are introducing information systems (IS) and quality management systems (QMS) [1], [2]. QMS ensures that products or services are always consistently supplied, meeting customer and applicable regulatory requirements and seeking to enhance customer satisfaction [3]. QMS are certified according to standard (ISO 9001 [4], CMMI [5] etc.) to approve QMS quality to the customers. IS can support and influence QMS processes [1] and it effectivity and efficiency.

In cases when product or service realization has been organized in the projects one of the main IS in organization is project management information system (PMIS). PMIS ensure wide range of functionality for different kind of projects and organizations and also different modification and customization options. Join design and integration of PMIS (or IS) and QMS provides increase of QMS efficiency [3].

The objective of this paper is to evaluate and demonstrate PMIS options for efficiency QMS development and maintenance. Requirements of QMS according to ISO 9001:2008 are summarized and the PMIS configuration options according to these requirements are demonstrated.

This paper is structured as follows. The second section has description of the PMIS functionality and configuration options. QMS structure and requirements has been described in Section 3. Definition of the PMIS configuration requirements according to the QMS requirements is presented in Section 4. Evaluation of efficiency improvement possibilities by using the PMIS configured according to the QMS requirements is summarized in the discussion section and conclusions are provided in the last section.

\section{PMIS FUNCTIONALITY AND CONFIGURATION}

PMIS is a standardized set of automated tools and techniques used in project management for planning, execution, management and closing of the project, as well as for collecting, combining and distributing project information [6]. PMIS provides a wide range of functions directly supporting PM [7], as well as tools for its configuration and modification. With configuration is defined the most appropriate PMIS configuration depending on project situation [8] [9]. Project situation requirements for PMIS have been identified according:

- Project classification [10] according project type, product, size, organization, management / planning approaches and related guidance's.

- Project environment and specific requirements.

- Enterprise environment factors [6] that includes enterprise available project management applications, government, industrial and quality standards etc. 
- Organizational process assets [6] that includes processes and procedures, for example, QMS (detail review of QMS in Section III.) and corporate knowledge base.

Definition of the PMIS configuration requirements must include the following information [8]:

1) Data entities or work items used in project;

2) Attributes or data fields of each data entity;

3) Processes or workflows related to the data entities.

Definition of the PMIS configuration requirements can also include records of data entity, for example, risk lists, reports, metrics etc.

\section{QMS OVERVIEW AND REQUIREMENTS}

QMS is process oriented framework [1] and ensures controlled performance of organization processes with target to deliver products or services according to customer and applicable regulatory requirements [3].

QMS according to ISO 9001 distinguish three types of processes: management, realization and support. QMS processes and its interaction within organization is being defined in the ISO 9001:2008 standard [11] and ISO 9004:2009 standard [12].

ISO 9001:2008 [11] defines quality policy, objectives, manual, management responsibility, resource management, documented procedures, work instructions, documents, records, measurements, analysis and improvement requirements. Most part of documented work instructions, documents and records have been related to realization processes.

ISO 9004:2009 [12] is guidance that describes how QMS according to ISO 9001:2008 can achieve sustained success with effective and efficient quality management approach. This guidance describes activities need to be done to ensure that organization processes and practices are effective and efficient. The self-assessment tool is used in the guidance for evaluation performance of an organization and degree of maturity of QMS [12]. The self-assessment tool evaluate maturity level of QMS key elements: management for the sustained success of organization; strategy and policy; resource management; process management; monitoring, measurement, analysis and review; improvement, innovation and learning [12]. The self-assessment can be done also for detailed elements.

Ensuring of QMS according to ISO 9001:2008 consists of two parts: adoption and maintenance. ISO 9001:2008 requirements have been introduced during adoption of QMS. Continues improvement is one of important part of QMS maintenance [13]. ISO 9004:2009 self-assessment tool [12] helps in identification of QMS gaps and possible improvements.

\section{QMS REQUIREMENTS TO PMIS CONFIGURATION}

In cases when product or service realization has been organized in the projects these requirements have been integrated in project processes, plans, metrics and records. The projects also need to collect measurement of metrics and key performance indicators (KPI) about processes and products for QMS analysis and improvement planning.

QMS according to ISO 9001:2008 defines common quality related requirement for the PMIS configuration for all projects in organization. The QMS requirements [11] and the PMIS configuration requirements relation is shown in Table I. The QMS requirements to the PMIS configuration are divided in two groups: product realization and measurements.

Main QMS requirements have been related to the project product realization and are identified from work instructions / procedures and its associated documents and records. In PMIS these requirements are implemented as data entities and workflows. As examples in Table I have been shown one ISO 9001 mandatory documented procedure 'Corrective actions' and three product realization processes: 'Requirement specification', 'Risk management' and 'Change management'.

Other set of the QMS requirements have been related to measurement of product and process quality. QMS defines quality metric and KPI. PMIS ensures definition of metrics and KPI and store of measurements values. Measurement values are analyzed centrally using reporting options of PMIS tools (for example MS Project Server reports [14]), data warehouse [15] or business intelligence tools (for example, also MS Project Server BI center [14]). Examples of metrics and KPI have been given in Table I.

The QMS requirements identify only part of the PMIS configuration requirements that gives quality baseline for the project. From the other project situation factors come the project specific PMIS requirements depending on project classification, environment, tools etc. As result other data entities, workflows and metrics can be included in the PMIS configuration and also modification in QMS defined PMIS configuration requirement can be done by including additional workflow statuses and data entity attributes.

\section{$\mathrm{V}$ DISCUSSION}

Application of PMIS contributes two areas of effective and efficient QMS development and maintenance: processes (also product realization) and monitoring.

Application of PMIS helps to improve effectivity and efficiency of QMS in following areas:

- Planning and control of organization product realization and other processes. During 
definition of the PMIS configuration requirements processes, process input/output, interactions, required records and measurements are identified. In PMIS integrated processes have been documented and partially automatized with data entity forms, workflows, review evidence records etc.

- Monitoring, measuring, analyzing, reviewing and reporting. Part of monitoring and measurement activities has been automatized by using PMIS. During definition of the PMIS configuration requirements have been identified metrics and KPI that need to be evaluated. Monitoring result help to assess and understand the organization current performance.

- Information distribution that helps to keep interested parties informed about progress against plans. PMIS collected data are easy available for reports.

TABLE I

QMS VS. PMIS CONFIGURATION REQUIREMENTS

\begin{tabular}{|c|c|c|c|c|c|}
\hline \multirow[b]{2}{*}{$\begin{array}{c}\text { QMS } \\
\text { REQUIREMENT }\end{array}$} & \multirow[b]{2}{*}{$\begin{array}{l}\text { PMIS CONFIGURATION } \\
\text { REQUIREMENT }\end{array}$} & \multicolumn{4}{|c|}{ EXAMPLE } \\
\hline & & $\begin{array}{c}\text { EXAMPLE 1: } \\
\text { CORRECTIVE ACTIONS } \\
\text { RELATED TO THE } \\
\text { PRODUCT }\end{array}$ & $\begin{array}{c}\text { EXAMPLE 2: } \\
\text { REQUIREMENT SPECIFICATION }\end{array}$ & $\begin{array}{c}\text { EXAMPLE 3: } \\
\text { RISK } \\
\text { MANAGEMENT }\end{array}$ & $\begin{array}{c}\text { EXAMPLE 4: } \\
\text { CHANGE } \\
\text { MANAGEMENT }\end{array}$ \\
\hline $\begin{array}{l}\text { Work } \\
\text { instructions and } \\
\text { procedures }\end{array}$ & $\begin{array}{l}\text { Different kind of } \\
\text { processes together with } \\
\text { related data entities. }\end{array}$ & $\begin{array}{l}\text { Data entity: Issue } \\
\text { Process: Issue status } \\
\text { workflow }\end{array}$ & $\begin{array}{l}\text { Data entity: Requirement, } \\
\text { Requirement specification (or } \\
\text { project documents with type } \\
\text { requirement specification), } \\
\text { Requirement specification } \\
\text { review (or document review) } \\
\text { Process: Requirement } \\
\text { management status workflow, } \\
\text { Requirement specification (or } \\
\text { project document) status } \\
\text { workflow }\end{array}$ & $\begin{array}{l}\text { Data entity: Risk } \\
\text { Process: Risk } \\
\text { status workflow }\end{array}$ & $\begin{array}{l}\text { Data entity: } \\
\text { Change request } \\
\text { Process: Change } \\
\text { request } \text { status } \\
\text { workflow }\end{array}$ \\
\hline Documents & $\begin{array}{l}\text { Forms of documents - } \\
\text { data entity with } \\
\text { attributes. }\end{array}$ & Attributes of issue & $\begin{array}{l}\text { Attributes of requirement, } \\
\text { (including requirement } \\
\text { traceability); } \\
\text { Template of requirement } \\
\text { specification; } \\
\text { Checklist of requirement } \\
\text { specification review }\end{array}$ & Attributes of risk & $\begin{array}{l}\text { Attribute of } \\
\text { change request }\end{array}$ \\
\hline $\begin{array}{l}\text { Records required } \\
\text { in ISO } 9001\end{array}$ & $\begin{array}{l}\text { Records are information } \\
\text { inserted in data entity } \\
\text { form or status transaction } \\
\text { in data entity workflow. } \\
\text { All required records need } \\
\text { to be include } \\
\text { configuration with data } \\
\text { entity or workflow status }\end{array}$ & $\begin{array}{l}\text { ISO } 9001 \text { requires } \\
\text { record "Nature of the } \\
\text { product } \\
\text { nonconformities and } \\
\text { any subsequent actions } \\
\text { taken, including } \\
\text { concessions obtained" } \\
\text { PMIS ensure this } \\
\text { requirement with issue } \\
\text { data entity, attributes } \\
\text { and workflow }\end{array}$ & $\begin{array}{l}\text { ISO } 9001 \text { requires record } \\
\text { "7.2.2. Results of the review of } \\
\text { requirements related to the } \\
\text { product and actions arising } \\
\text { from the review" } \\
\text { PMIS ensure this requirement } \\
\text { with requirement workflow } \\
\text { status } \\
\text { " } 7.5 .3 \text {. The unique } \\
\text { identification of the product, } \\
\text { where traceability is a } \\
\text { requirement" } \\
\text { PMIS ensure this requirement } \\
\text { with requirement and } \\
\text { requirement specification data } \\
\text { entity attribute }\end{array}$ & & $\begin{array}{l}\text { ISO } 9001 \\
\text { requires record } \\
\text { "7.3.7. Results of } \\
\text { the review of } \\
\text { design and } \\
\text { development } \\
\text { changes and any } \\
\text { necessary } \\
\text { actions" } \\
\text { PMIS ensure this } \\
\text { requirement with } \\
\text { change request } \\
\text { data entity, } \\
\text { attributes and } \\
\text { workflow }\end{array}$ \\
\hline
\end{tabular}




\begin{tabular}{|c|c|c|c|c|c|}
\hline Metrics & $\begin{array}{l}\text { Metrics data entity with } \\
\text { defined metric records } \\
\text { Measurement data entity }\end{array}$ & $\begin{array}{l}\text { For example "Issues in } \\
\text { product / project / } \\
\text { project phase" }\end{array}$ & $\begin{array}{l}\text { For example } \\
\text { "Count of requirements in } \\
\text { product / project / project } \\
\text { phase" } \\
\text { "Count of changed } \\
\text { requirements in product / } \\
\text { project / project phase" } \\
\text { "Count of requirements } \\
\text { changes in product / project / } \\
\text { project phase" } \\
\text { "Count of corrections in } \\
\text { requirement specification } \\
\text { during review" }\end{array}$ & $\begin{array}{l}\text { For example } \\
\text { "Risks (identified, } \\
\text { removed / } \\
\text { occurred ) in } \\
\text { product / project / } \\
\text { project phase" } \\
\text { "Reviews to risk" } \\
\text { "Count of risk } \\
\text { occurrence" }\end{array}$ & $\begin{array}{l}\text { For example } \\
\text { "Changes in } \\
\text { product / project } \\
\text { / project phase" }\end{array}$ \\
\hline KPI & $\begin{array}{l}K P I \text { data entity with } \\
\text { defined metric records }\end{array}$ & $\begin{array}{l}\text { For example "Critical } \\
\text { issues per product / } \\
\text { project / project phase" } \\
\text { (Target value: zero) }\end{array}$ & $\begin{array}{l}\text { For example "Count of } \\
\text { corrections in requirement } \\
\text { specification during review per } \\
\text { product / project / project } \\
\text { phase" (the more the better, for } \\
\text { example target value: } 10 \text { ) }\end{array}$ & $\begin{array}{l}\text { For example } \\
\text { "Count of not } \\
\text { reviewed risk } \\
\text { occurrence per } \\
\text { product / project / } \\
\text { project phase" } \\
\text { (Target value: } \\
\text { zero) }\end{array}$ & \\
\hline
\end{tabular}

According to the self-assessment tool [12] maturity level achievement of following QMS elements are easier by using PMIS:

- Process planning and control - key processes are defined and managed, interactions are defined and systematically measured (Level 2 ).

- Monitoring - monitoring process is performed periodically (Level 2 ), process capabilities are monitored (Level 3).

- KPI - formal set of defined key indicators (Level 2), main conditions for success are identified and tracked by indicators (Level 3), management decisions are supported by reliable data (Level 3), data is available to show progress of KPI over time (Level 4), strategy and objectives is monitored (Level 4).

- Analysis - statistical tools are used (Level $2,3)$.

Application of PMIS only helps to easier achieve maturity levels because PMIS can be implemented only QMS defined requirements. PMIS is only tool for QMS implementation that helps to create it more efficient. To achieve each level the first is required improvements in QMS and then in PMIS and other organization IS.

\section{CONCLUSION}

PMIS is one of IS that is used for QMS support and implementation in the project oriented organization. This paper demonstrates PMIS options for efficiency QMS development and maintenance. PMIS contributes two areas of QMS: project product realization and monitoring of product quality and processes. Application of PMIS helps to develop QMS effective and efficient according to ISO 9001:2008 but also is need other organization IS that contributes other areas of the QMS requirements.
Limitation of this research is that only QMS according to ISO 9001:2008 for project oriented product realization has been reviewed and analyzed.

This is background research about PMIS options in the QMS requirement implementation. Future research directions are QMS integration with portfolio management systems and business intelligence tools for the project quality data analytics and the quality process monitoring.

\section{REFERENCES}

[1] S. G. G. Ferreira and J. Á. Carvalho, "Articulation between information systems and quality management systems," in Creating Global Competitive Economies: A 360-Degree Approach - Proceedings of the 17th International Business Information Management Association Conference, IBIMA 2011, 2011, vol. 4, pp. 2111-2113.

[2] L. Y. Fok, W. M. Fok, and S. J. Hartman, "Exploring the relationship between total quality management and information systems development," Inf. Manag., vol. 38, no. 6, pp. 355-371, Jul. 2001.

[3] P. R. da Cunha and A. D. de Figueiredo, "Quality Management Systems and Information Systems: Getting More than the Sum of the Parts," AMCIS 2005 Proc., 2005.

[4] ISO, ISO 9000 quality management.

[5] "CMMI Institute." [Online]. Available: http://cmmiinstitute.com/. [Accessed: 18-Mar-2015].

[6] Project Management Institute, $A$ Guide to the Project Management Body of Knowledge ( PMBOK® Guide )—Fifth Edition. PMI, 2014, p. 618.

[7] S. Bērziša, "The Baseline Configuration of Project Management Information System," Sci. J. Riga Tech. Univ. Comput. Sci., vol. 5, no. 40, pp. 59-65, 2009.

[8] S. Bērziša, "Application of Knowledge and Best Practices in Configuration of Project Management Information Systems," PhD thesis, Riga Technical university, 2012.

[9] S. Bērziša and J. Grabis, "Knowledge Reuse in Configuration of Project Management Information Systems: A Change Management Case Study," in Proceedings of the 15th IEEE International Conference on Intelligent Engineering Systems 2011, 2011, pp. 51-56.

[10] S. Bērziša, "Project Management Knoeldege Retrieval: Project Classification," in Enviroment. TEechnology. Resources: Proceedings of the 8-th International Scientific and Practical 
Solvita Berzisa / Environment. Technology. Resources, (2015), Volume III, 17-21

Conference June 20-22,2011. Volume II, 2011, vol. I, pp. 33 39.

[11] ISO, ISO 9001:2008 - Quality management systems -Requirements.

[12] ISO, ISO 9004:2009 - Managing for the sustained success of an organization -- A quality management approach.

[13] I. Mustapha, A. Jusoha, and K. M. Nora, "A review on quality management systems maintenance framework based on process based management, Knowledge quality and knowledge self-efficacy," J. Teknol., vol. 72, no. 4, pp. 7-12, 2015.

[14] "Project Server 2013 - PWA Sample BI Reports." [Online]. Available:

http://epmcentral.com/articles/ps13/ ps13samplereports.php. [Accessed: 20-Mar-2015].

[15] N. Gojgic, A. Veljovic, M. Zahorjanski, L. Stanojevic, and N. Cvijovic, "Implementation of data warehouse in analysis of QMS inconsistencies," Metal. Int., vol. 17, no. 3, pp. 5-10, 2012 . 